\title{
Profil Penderita Liken Simpleks Kronikus Di Puskesmas Padang Pasir Kota Padang Tahun 2017
}

\author{
Sari, $\mathrm{DP}^{1}$, Primawati, $\mathrm{I}^{2}, \mathrm{Akbar}, \mathrm{RR}^{3}$
}

\author{
${ }^{1}$ Mahasiswa Fakultas Kedokteran Univeristas Baiturrahmah, Padang, Indonesia \\ Email : ditapurnama427@gmail.com \\ ${ }^{2}$ Bagian Ilmu Kulit Kelamin, Dosen Fakultas Kedokteran Univeristas Baiturrahmah, Padang, Indonesia. \\ ${ }^{3}$ Medical Education Unit, Dosen Fakultas Kedokteran Univeristas Baiturrahmah, Padang, Indonesia.
}

\begin{abstract}
Abstrak
Latar Belakang: Liken Simpleks Kronikus (LSK) merupakan peradangan kulit kronis, gatal, sirkumskripta yang mengalami peningkatan insiden akhir-akhir ini, namun pada penelitian sebelumnya masih terdapat perbedaan mengenai profil LSK sehingga pentingnya pembaharuan epidemiologi LSK agar dapat dijadikan landasan teori terbaru bagi penelitian, pendidikan, institusi kesehatan dan masyarakat.Tujuan: Penelitian ini bertujuan untuk mengetahui profil penderita Liken Simpleks Kronikus di Puskesmas Padang Pasir tahun 2017 yang mencakup distribusi frekuensi berdasarkan usia, jenis kelamin, keluhan utama, lokasi lesi dan terapi. Metode: Penelitian ini merupakan penelitian deskriptif yang menggunakan data sekunder yang berasal dari rekam medis pasien LSK di Puskesmas Padang Pasir Kota Padang pada tahun 2017. Sampel penelitian sebanyak 70 orang yang diperoleh dengan teknik total sampling dan rumus slovin. Hasil penelitian diperoleh distribusi frekuensi penderita LSK berdasarkan kelompok usia terbanyak adalah 56-65 tahun (34,3\%) dengan jumlah pasien perempuan lebih banyak $(51,4 \%)$ daripada laki-laki $(48,6 \%)$. Keluhan utama terbanyak yaitu gatal $(82,9 \%)$, lokasi lesi yang tersering adalah kaki (54,3\%) dan terapi antihistamin oral yang paling banyak diberikan adalah Klorferamini Maleat (CTM) 4mg (72,9\%), terapi steroid oral terbanyak Dexametason 0,5 mg $(28,6 \%)$ dan terapi topikal terbanyak adalah Betametason $0,1 \% \mathrm{krim}(51,4 \%)$. Kesimpulan: Distribusi frekuensi penderita LSK berdasarkan usia didapatkan kelompok usia terbanyak kasus LSK adalah 56 - 65 tahun berjumlah $24(34,3 \%)$ orang pasien, hal ini terjadi karena pada periode ini penderita cenderung mengalami gangguan psikologis dan psikiatri
\end{abstract}

\section{Kata Kunci --Epidemiologi, Liken Simpleks Kronikus}

\begin{abstract}
Background: Lichen simplex chronicus (LSC) is a chronic, itching, circumscribed, inflammation disorder of skin, which the incident rate has increasing lately. Previous studies show some differences regarding LSC profiles. It is important to update the epidemiology of LSC so that it can be used as a new theoretical basis for research, society and health institutions. Objective: This study aimed to find out the profile of Lichen Simplex Chronicus in Puskesmas Padang Pasir in 2017 which includes distribution of frequency based on age, gender, major complaints, location of lesion, and therapy. Method:This is a descriptive study where the data was obtained from medical record of LSK 70 patients in Puskesmas Padang Pasir in January - December 2017. The sample size was calculated by total sampling technique and slovin formula. Results show distribution of frequency: mostly, the age distribution was 56-65 years old (34,3\%), and the number of women patients $(51,4 \%)$ were more than male patients (48,6\%). The most complained symptom and affected site was itching (82,9\%) and foot (54,3\%). The most used antihistamine therapy was chlorpheniramine maleate $4 \mathrm{mg}$ (72,9\%), the most used oral steroid therapy was dexamethasone $0,5 \mathrm{mg}(28,6 \%)$ and the most topical therapy was betamethasone 0,1\% cream (51,4\%).Conclusion: The frequency distribution of LSK sufferers based on age found that the most age group of cases of LSK was 56 - 65 years, amounting to 24 (34.3\%) patients, this happened because in this period patients tended to experience psychological and psychiatric disorders.
\end{abstract}




\section{Pendahuluan}

Liken Simpleks Kronikus (LSK) merupakan peradangan kulit kronis, gatal, sirkumskripta, ditandai dengan kulit tebal dan garis kulit tampak menonjol (likenifikasi) menyerupai kulit batang kayu, akibat garukan dan gosokan berulang-ulang karena berbagai ransangan pruritogenik. Penyakit ini juga dikenal sebagai neurodermatitis sirkumskripta atau liken vidal. ${ }^{1}$

Liken Simpleks Kronikus merupakan penyakit kulit kronis umum dan tidak menular yang mempengaruhi hingga $12 \%$ dari total populasi dunia. ${ }^{2}$ Belum ada sumber yang jelas menyebutkan berapa jumlah penderita LSK tiap tahunnya di Indonesia. ${ }^{1}$

Beberapa literatur menyatakan bahwa, LSK sering terjadi pada kelompok usia 30-50 tahun. ${ }^{3}$ LSK dapat terjadi pada onset yang lebih muda yaitu rata-rata 19 tahun pada pasien dengan riwayat dermatitis atopik, ${ }^{4}$ namun berdasarkan survey awal yang dilakukan oleh peneliti di Puskesmas Padang Pasir terdapat pasien LSK yang berusia 13 tahun.

Terjadi peningkatan insiden penderita LSK di RS DR. M. Djamil Padang, hal ini berdasarkan survey awal di divisi Dermatologi non Infeksi Poliklinik Kulit dan Kelamin RSUP Dr. M. Djamil Padang yaitu sebesar 28 pasien pada tahun 2013 menjadi 77 pasien pada tahun 2014. LSK merupakan kasus terbanyak di Divisi Dermatologi non Infeksi Poliklinik Kulit dan Kelamin RS DR. M. Djamil Padang yaitu dengan kunjungan sebanyak 144 kunjungan pada tahun $2015 .^{5}$

Berdasarkan survey awal yang dilakukan oleh peneliti, mengacu kepada Laporan Bulanan Data Kesakitan Puskesmas Padang Pasir, diperoleh data bahwa LSK merupakan lima insiden penyakit kulit tertinggi di Puskesmas Padang Pasir selama periode
Januari- Desember tahun 2017.

Liken Simpleks Kronikus sering terjadi pada wanita daripada pria dengan rasio $2: 1 .^{5}$ LSK dapat terjadi pada setiap permukaan tubuh, ${ }^{6}$ gejala utama penderita LSK yang paling sring adalah gatal, ${ }^{7,8}$ penggunaan terapi paling banyak menggunakan kortikosteroid topical desoksimethasone $0,25 \%$. $^{7}$

Penelitian ini bertujuan untuk mengetahui profil penderita LSK di Puskesmas Padang Pasir Kota Padang periode Januari-Desember 2017 yang mencakup usia, jenis kelamin, keluhan utama, lokasi lesi, dan terapi.

\section{Metode Penelitian}

Penelitian ini dilakukan pada bulan AprilDesember 2018. Jenis penelitian ini adalah deskriptif dengan memanfaatkan data rekam medik pasien LSK di Puskesmas Padang Pasir, Kota Padang pada periode JanuariDesember 2017. Besar populasi sebanyak 90 orang, dan didapatkan sampel sebanyak 70 orang yang diperoleh dengan teknik total sampling dan rumus slovin dengan batas toleransi kesalahan sebesar 5\%.

\section{HASIL}

Tabel 1. Distribusi Frekuensi Penderita LSK BERDASARKAN USIA

\begin{tabular}{llll}
\hline Usia & $\mathbf{N}$ & $\mathbf{\%}$ & IK 95\% \\
\hline $0-5$ tahun & 0 & 0 & \\
$5-11$ tahun & 0 & 0 & \\
$12-16$ tahun & 1 & 1,4 & $0.0-4,3$ \\
$17-25$ tahun & 1 & 1,4 & $0,0-4,3$ \\
$26-35$ tahun & 0 & 0 & \\
$36-45$ tahun & 5 & 7,1 & $1,4-14,3$ \\
$46-55$ tahun & 16 & 22,9 & $14,3-32,9$ \\
$56-65$ tahun & 24 & 34,3 & $24,3-47,1$ \\
$\geq 66 \quad$ tahun & 23 & 32,9 & $21,4-42,9$ \\
\hline Total & $\mathbf{7 0}$ & $\mathbf{1 0 0}$ & \\
\hline
\end{tabular}

Berdasarkan Tabel 1 diatas dari 70 responden diperoleh hasil distribusi kelompok usia terbanyak kasus LSK adalah pada rentang usia 56 - 65 tahun berjumlah 24 orang pasien $(34,3 \%)$, diikuti kelompok usia 
lebih dari 66 tahun yaitu sebanyak 23 $(32,9 \%)$ pasien, serta didapatkan kasus LSK dengan kelompok usia terendah yaitu 12-16 tahun sebanyak 1 orang $(1,4 \%)$ dan tidak didapatkan kasus LSK pada anak usia $\leq 11$ tahun dan pada kelompok usia 26-35 tahun.

TABel 2. Distribusi FrekUENSI Penderita LSK BERDASARKAN JENIS KELAMIN

\begin{tabular}{llll}
\hline Jenis Kelamin & N & \% & IK 95\% \\
\hline Perempuan & 36 & 51,4 & $40.0-62.9$ \\
Laki-laki & 34 & 48,6 & $37.1-60.0$ \\
\hline Total & $\mathbf{7 0}$ & $\mathbf{1 0 0}$ & \\
\hline
\end{tabular}

Berdasarkan tabel 2 di atas, distribusi jenis kelamin pasien LSK lebih banyak pada perempuan yaitu sebanyak 36 orang $(51,4 \%)$, dan distribusi pasien LSK pada laki - laki sebanyak 34 orang $(48,6 \%)$.

Tabel 3. Distribusi Frekuensi Penderita LSK BERDASARKAN KELUHAN UTAMA

\begin{tabular}{llll}
\hline Keluhan Utama & $\mathbf{N}$ & \% & IK 95\% \\
\hline Gatal & 58 & 82,9 & $74.3-91.4$ \\
Bercak merah & 4 & 5,7 & $1.4-11.4$ \\
Kulit menebal & 3 & 4,3 & $0.0-10.0$ \\
Kulit berair & 3 & 4,3 & $0.0-10.0$ \\
Bercak hitam & 1 & 1,4 & $0.0-4.3$ \\
Kulit pecah-pecah & 1 & 1,4 & $0.0-4.3$ \\
\hline Total & $\mathbf{7 0}$ & $\mathbf{1 0 0}$ & \\
\hline
\end{tabular}

Berdasarkan tabel 3 diatas, terdapat keluhan utama terbanyak kasus LSK di Puskesmas Padang Pasir tahun 2017 adalah keluhan gatal yaitu sebanyak 58 pasien atau sebesar $82,9 \%$, diikuti dengan keluhan bercak merah sebanyak 4 orang $(5,7 \%)$, keluhan kulit menebal dan kulit berair masing - masing sebanyak tiga orang pasien dengan persentase masing-masing sebesar 4,3\%. Kasus LSK dengan keluhan utama yang paling sedikit adalah keluhan kulit pecahpecah dan bercak hitam yaitu masing-masing 1 orang dengan persentase sebesar $1,4 \%$.

Tabel 4. Distribusi Frekuensi Penderita LSK BERDASARKAN LOKASI LESI

\begin{tabular}{llll}
\hline Lokasi Lesi & N & \% & IK 95\% \\
\hline Badan & 17 & 24,3 & $14.3-34.3$ \\
Siku & 1 & 1,4 & $0.0-4.3$ \\
Tangan & 10 & 14,3 & $7.1-22.9$ \\
\hline
\end{tabular}

\begin{tabular}{llll}
\hline Tungkai atas & 2 & 2,9 & $0.0-7.1$ \\
Lutut & 2 & 2,9 & $0.0-7.1$ \\
Kaki & 38 & 54,3 & $42.9-65.7$ \\
\hline Total & $\mathbf{7 0}$ & $\mathbf{1 0 0}$ & \\
\hline
\end{tabular}

Berdasarkan tabel diatas, lokasi lesi terbanyak didapatkan pada kaki yaitu sebanyak 38 kasus atau sebesar 54,3\% dan kasus LSK dengan lokasi lesi yang paling sedikit adalah pada siku berjumlah 1 orang kasus dengan persentase sebesar $1,4 \%$.

TABel 5.1 Distribusi FrekUENSI PENDERITA LSK BERDASARKAN TERAPI ANTIHISTAMIN ORAL

\begin{tabular}{|c|c|c|c|}
\hline Jenis Obat & $\mathbf{N}$ & $\%$ & IK $95 \%$ \\
\hline $\begin{array}{l}\text { Klorfeniramini } \\
\text { (CTM) } 4 \mathrm{mg}\end{array}$ & 51 & 72,9 & $62.9-82.9$ \\
\hline Loratadin $10 \mathrm{mg}$ & 17 & 24,3 & $14.3-34.3$ \\
\hline $\begin{array}{l}\text { Tidak memakai } \\
\text { Antihistamin oral }\end{array}$ & 2 & 2,9 & $0.0-7.1$ \\
\hline Total & 70 & 100 & \\
\hline
\end{tabular}

Berdasarkan tabel di atas, pemberian terapi antihistamin oral terbanyak adalah Klorfeniramini Maleat (CTM) $4 \mathrm{mg}$ yaitu 51 pasien $(72,9 \%)$, diikuti dengan Loratadin 10 mg sebanyak 17 orang kasus $(24,3 \%)$, dan terdapat 2 orang pasien yang tidak diberikan terapi antihistamin oral.

\section{Tabel 5 Distribusi Frekuensi Penderita LSK} BERDASARKAN TERAPI STEROID ORAL

\begin{tabular}{llll}
\hline Jenis Obat & N & \% & IK 95\% \\
\hline Dexametason 0,5 mg & 20 & 28,6 & $18.6-40.0$ \\
Metilprednisolon 4 mg & 4 & 5,7 & $1.4-11.4$ \\
\hline $\begin{array}{l}\text { Tidak memakai steroid } \\
\text { oral }\end{array}$ & 46 & 65,7 & $54.3-75.7$ \\
\hline Total & $\mathbf{7 0}$ & $\mathbf{1 0 0}$ & \\
\hline
\end{tabular}

Berdasarkan tabel diatas, hasil penelitian mengenai terapi steroid oral, didapatkan pemakaian terapi terbanyak adalah Deksametason 0,5 mg yaitu sebanyak 20 pasien $(28,6 \%)$, diikuti dengan pemberian terapi Metilprednisolon $4 \mathrm{mg}$ sebanyak 4 orang atau sebesar $5,7 \%$ dan terdapat 46 pasien yang tidak diberikan terapi steroid oral.

Tabel 6 Distribusi Frekuensi Penderita LSK BERDASARKAN TERAPI TOPIKAL 


\begin{tabular}{llll}
\hline Jenis Obat & N & \% & IK 95\% \\
\hline Betametason 0,1\% krim & 36 & 51,4 & $40.0-62.9$ \\
Hidrokortison 1\% krim & 6 & 8,6 & $2.9-15.7$ \\
Hidrokortison 2,5\% & 9 & 12,9 & $5.7-21.4$ \\
Salisil bedak 2\% & 4 & 5,7 & $1.4-11.4$ \\
$\begin{array}{l}\text { Tidak memakai terapi } \\
\text { topikal }\end{array}$ & 15 & 21,4 & $11.5-31.4$ \\
\hline Total & & & \\
\hline
\end{tabular}

Berdasarkan tabel diatas, pemberian terapi topikal terbanyak adalah Betametason $0,1 \%$ krim sebanyak 36 orang, diikuti hidrokortison $2,5 \%$ sebanyak 9 orang dan hidrokortison $1 \%$ sebanyak 6 orang dan pemberian terapi topikal yang paling sedikit adalah salisil bedak $2 \%$.

\section{Pembahasan}

\section{A. Distribusi Frekuensi Penderita LSK Berdasarkan Usia}

Berdasarkan penelitian ini didapatkan distribusi pasien LSK dengan jumlah terbanyak berada dikategori usia 56-65 tahun sebanyak $24(34,3 \%)$ pasien. LSK paling sering terjadi pada masa lansia akhir karena pada periode ini penderita cenderung mengalami gangguan psikologis dan psikiatri, dimana pasien memiliki kepekaan yang tinggi terhadap sensasi gatal, harga diri yang rendah, mengubah citra tubuh, kecemasan, perasaan tidak berdaya, dan pengalaman psikososial negatif. ${ }^{9}$

Pada penelitian ini terdapat kasus LSK pada kelompok usia terendah 12-16 tahun yaitu satu subjek penelitian yang berusia 13 tahun, tidak terdapat pasien LSK pada usia dibawah 11 tahun. Hal ini dapat terjadi jika penderita memiliki riwayat dermatitis atopik. Hipotesis yang mendasarinya yaitu terjadinya peningkatan Imunoglobulin $\mathrm{E}$ dan kulit cenderung pada kondisi eksim sehingga lebih rentan terhadap likenifikasi. ${ }^{10,11}$

\section{B. Distribusi Frekuensi Penderita LSK Berdasarkan Jenis Kelamin}

Hasil penelitian ini menunjukan bahwa perempuan lebih cenderung mengalami LSK dibandingkan dengan laki-laki dengan perbandingan $51,4 \%$ berbanding $48,6 \%$. Meskipun hasil ini tidak memberikan perbandingan yang signifikan, hal ini terjadi karena banyaknya sampel yang berjenis kelamin perempuan termasuk kedalam kriteria eklusi sehingga tidak dapat dimasukan kedalam sampel data penelitian yaitu sebanyak 14 orang perempuan dan hanya 6 orang laki-laki.

Berdasarkan penelitian oleh Ramon Martin.,dkk menyatakan bahwa perempuan lebih cenderung dengan kasus LSK daripada laki-laki dengan hasil terdapat 10 kasus lakilaki $(16,7 \%)$ dan 50 orang kasus perempuan $(83,3){ }^{13}$ Literatur dan hasil penelitian lainnya juga didapatkan kesimpulan bahwa perempuan lebih cenderung untuk kasus LSK daripada laki-laki. ${ }^{7,10,14}$

Perempuan lebih cenderung mengalami masalah kesehatan mental daripada lakilaki. ${ }^{15}$ Sebuah penelitian menyatakan bahwa perempuan menunjukan lebih banyak kepekaan terhadap hubungan antar pribadi, sedangkan laki-laki lebih menunjukan kepekaan terhadap karier eksternal dan faktor-faktor yang berorientasi pada tujuan. Kondisi gangguan disforik pramenstruasi, depresi pasca persalinan, depresi dan kecemasan pasca menopause yang berhubungan dengan perubahan hormon ovarium yang dapat berkontribusi pada peningkatan prevalensi pada perempuan. ${ }^{15}$

Banyak bukti dari literatur menunjukan bahwa perjalanan dari banyak gangguan kulit dipengaruhi oleh stress dan peristiwa psikologis. Sebuah penelitian menyatakan adanya hubungan antara kulit dengan otak, bahwa otak sebagai pusat fungsi psikologis dan kulit memiliki asal neuroektodermal embrionik yang sama dan dipengaruhi oleh hormon dan neurotransmitter yang sama. ${ }^{18}$ Tekanan psikologis menganggu homeostatis barier permeabilitas epidermis, dan dapat 
bertindak sebagai pencetus untuk beberapa gangguan peradangan pada kulit. ${ }^{19}$

\section{Distribusi Frekuensi Penderita LSK Berdasarkan Keluhan Utama}

Berdasarkan hasil penelitian ini, didapatkan keluhan utama terbanyak yaitu gatal sebanyak $58(82,9 \%)$ kasus LSK. Hasil ini sejalan dengan beberapa literatur dan penelitian oleh Paramita dan Thappa yang menyatakan bahwa gatal merupakan keluhan utama terbanyak yaitu sebesar $90,3 \%$. ${ }^{1,7,10,12}$

Gatal biasanya dirasakan cukup hebat terutama saat malam hari dan saat tidak sedang melakukan suatu aktivitas. Gatal sendiri timbul akibat pelepasan mediator inflamasi dan aktivitas enzim proteolitik, keadaan ini menimbulkan-terjadinya proses inflamasi pada kulit yang menyebabkan penderita sering menggaruk lesi yang terbentuk. ${ }^{4}$

Keparahan gatal dapat diperburuk dengan berkeringat, suhu, iritasi pakaian, dan saat terjadi stress psikologis. ${ }^{20}$ Sebuah penelitian melaporkan keparahan gatal yang memburuk karena panas dan berkeringat dapat terjadi karena neuron $\mathrm{C}$ spesifik pruritus yang sensitif terhadap suhu, hal ini dapat menjelaskan pengamatan bahwa gatal lebih buruk di lingkungan yang hangat. ${ }^{12}$

Berdasarkan hasil penelitian ini, bercak merah menempati posisi keluhan terbanyak setelah gatal dengan persentase $5,7 \%$. Eritema biasanya muncul pada awal lesi. Lesi pada LSK umumnya bermanifestasi sebagai plak tunggal atau multipel yang tidak beraturan atau berbentuk poligon dengan papula merah yang sedikit lebih tinggi. ${ }^{20}$

Terdapat keluhan utama kulit menebal dan kulit berair masing-masing sebanyak 3 orang. Penebalan kulit dapat terjadi karena iritasi dan inflamasi yang terus menerus menyebabkan dilakukannya garukan yang terus-menerus sehingga terjadinya penebalan kulit $^{21}$ gesekan yang disebabkan oleh pakaian dan goresan juga bisa memperburuk penyakit atau menimbulkan likenifikasi. ${ }^{22}$ Penebalan kulit atau plak likenifikasi ini dapat memprovokasi gatal sehingga menyebabkan kondisi kulit kronis oleh siklus gatal-garuk. $^{13}$

Berdasarkan hasil penelitian ini, keluhan bercak hitam dan kulit pecah-pecah masingmasing sebanyak satu orang. Keluhan bercak hitam dapat terjadi pada area yang mengalami likenifikasi yang menjadi coklat kehitaman karena pigmen hemosiderin. Garukan yang berulang juga dapat menyebabkan bagian lesi kering, berskuama, dan ekskoriasi. ${ }^{23}$

\section{Distribusi Frekuensi Penderita LSK \\ Berdasarkan Lokasi Lesi}

Berdasarkan penelitian ini lokasi LSK tersering terdapat di daerah kaki yaitu sebesar 54,3\%. Hasil ini sejalan dengan penelitian yang dilakukan oleh Paramita dan Sunarso yang menyatakan bahwa lokasi terbanyak kasus LSK didapatkan pada kaki yaitu sebesar $45,2 \%{ }^{7}$

Liken Simpleks Kronikus ditemukan pada kulit didaerah yang mudah dijangkau untuk menggaruk. ${ }^{24}$ Lesi yang timbul dapat muncul hanya pada satu tempat, tetapi dapat juga dijumpai pada beberapa tempat. ${ }^{4}$ Pada penelitian ini didapatkan beberapa pasien dengan lokasi lesi lebih dari satu tempat, namun peneliti hanya mengambil satu lokasi lesi yang cenderung berulang disetiap kali pasien datang ke Puskesmas Padang Pasir dengan keluhan LSK.

\section{E. Distribusi Frekuensi Penderita LSK Berdasarkan Terapi}

Terapi terbaik untuk LSK yaitu terapi internal (terapi psikologis) dan terapi eksternal (medikamentosa). Pada penelitian ini, peneliti membatasi terapi LSK hanya pada terapi medikamentosa yang dikelompokan menjadi terapi antihistamin oral, terapi steroid oral dan terapi-topikal. 
Tidak terdapat laporan mengenai terapi antibiotik, hal ini sesuai dengan hasil penelitian mengenai keluhan utama pasien yaitu tidak terdapat pasien dengan keluhan infeksi.

\section{1) Distribusi Frekuensi Penderita LSK}

Berdasarkan Terapi Antihistamin Oral

Antihistamin sistemik bekerja secara primer dengan menghambat reseptor $\mathrm{H} 1$ pada dermis. Antihistamin dapat memperbaiki gejala pruritus karena histamin adalah mediator yang menginduksi prutitus pada kulit. Hasil penelitian ini menunjukan bahwa pemberian terapi antihistamin oral terbanyak adalah Klorfeniramini Maleat (CTM) $4 \mathrm{mg}$ yaitu 51 pasien $(72,9 \%)$, diikuti dengan Loratadin $10 \mathrm{mg}$ sebanyak 17 orang kasus $(24,3 \%)$, dan terdapat 2 orang pasien yang tidak diberikan terapi antihistamin oral.

Klorfeniramini Maleat (CTM) merupakan antihistamin generasi pertama dan Loratadin merupakan antihistamin generasi kedua. CTM termasuk antagonis H1 yang paling kuat. Antihistamin generasi pertama ini sering bermanifestasi berupa melambatnya waktu muncul reaksi dan efek mengantuk(somnolen), ${ }^{26}$ efek sedasi ini bermanfaat bagi beberapa pasien yang mengalami gangguan kualitas tidur akibat gatal yang sering terjadi pada malam hari. Kecendrungan obat-obat ini menyebabkan kantuk lebih kecil dibandingkan antagonis H1 lain sehingga obat ini juga cocok untuk pemakaian siang hari. ${ }^{26}$

Berbeda dengan antihistamin generasi kedua seperti loratadin dimana obat ini tidak dapat melintasi sawar darah otak sehingga tidak berefek sedasi, antihistamin generasi kedua cenderung memiliki efek samping yang lebih ringan daripada antihistamin generasi pertama, efek samping seperti rasa kering dimulut dan-saluran nafas serta retensi urin yang sering diakibatkan pemakaian beberapa antagonis reseptor $\mathrm{H} 1$ dapat dihindari. ${ }^{26}$

\section{2) Distribusi Frekuensi Penderita LSK}

Berdasarkan Terapi Topikal

Terapi topikal terbanyak untuk kasus LSK adalah Betametason 0,1\% krim sebanyak 36 orang, diikuti hidrokortison $2,5 \%$ krim sebanyak 9 orang selanjutnya terapi hidrokortison $1 \%$ sebanyak 6 orang. Sedangkan pemakaian terapi topikal yang paling sedikit adalah salisil bedak $2 \%$ yaitu sebanyak 4 orang dan terdapat 15 orang yang tidak diberikan terapi topikal.

Kebanyakan obat topikal memiliki absorbsi sistemik yang dapat diabaikan sehingga memiliki efek samping lebih sedikit. ${ }^{27}$ Pemberian steroid topikal dapat membantu mengurangi hiperketatosis. ${ }^{20}$ Berdasarkan hasil penelitian ini, Betametason dipropionate merupakan terapi steroid topikal terbanyak yang diberikan. Berdasarkan literatur, betametason dipropionat merupakan steroid topikal yang sangat paten untuk terapi LSK. Terapi diberikan sekali atau dua kali sehari selama dua minggu diikuti dengan tahap istirahat selama satu minggu. Namun efek samping obat ini berupa atrofi kulit dan supresi adrenal. ${ }^{28}$

Pemakaian terapi topikal yang paling banyak selanjutnya adalah hidrokortison asetat 2,5\% krim sebesar $12,9 \%$. Hidrokortison asetat merupakan kortikosteroid topikal yang mempunyai efek anti-inflamasi, antipruritus dan vasokonstriksi.29 Pada penelitian ini, pemberian salisil bedak $2 \%$ yaitu sebesar $5,7 \%$. Bedak salisil mengandung menthol yang memberikan efek dingin pada kulit, sehingga dapat mengurangi gatal. ${ }^{4}$

3) Distribusi Frekuensi Penderita LSK

Berdasarkan Terapi Steroid Oral

Berdasarkan hasil penelitian ini, didapatkan pemakaian terapi steroid oral terbanyak adalah Deksametason 0,5 mg yaitu sebanyak 20 pasien $(28,6 \%)$, diikuti dengan pemberian terapi Metilprednisolon $4 \mathrm{mg}$ sebanyak 4 orang atau sebesar $5,7 \%$. Steroid sistemik ini diberikan jika pemakaian steroid topikal 
selama dua minggu tidak memberikan hasil yang efektif. ${ }^{22}$

Pada penelitian ini, terdapat 46 pasien $(65,7 \%)$ yang tidak diberikan terapi steroid oral. Banyaknya pasien yang tidak diberikan steroid oral karena terapi dengan steroid topikal yang poten dan antihistamin sudah berespon lebih baik terhadap peradangan pada LSK. ${ }^{27}$

\section{Kesimpulan Dan Saran}

Distribusi frekuensi penderita LSK berdasarkan usia didapatkan kelompok usia terbanyak kasus LSK adalah 56 - 65 tahun berjumlah $24(34,3 \%)$ orang pasien, hal ini terjadi karena pada periode ini penderita cenderung mengalami gangguan psikologis dan psikiatri. Terdapat pasien LSK pada kelompok usia 12-16 tahun, hal ini dapat terjadi jika penderita memiliki riwayat dermatitis atopi. Penderita LSK berdasarkan jenis kelamin lebih banyak pada perempuan yaitu sebanyak 36 orang $(51,4 \%)$, hal ini terkait dengan masalah kesehatan mental yang lebih cenderung terjadi pada perempuan. Keluhan utama terbanyak adalah keluhan gatal yaitu $58 \quad(82,9 \%)$ orang, gatal timbul akibat pelepasan mediator inflamasi dan aktifitas enzim poteolitik. Lokasi lesi terbanyak didapatkan pada kaki yaitu sebanyak 38 kasus atau sebesar 54,3\%, LSK ditemukan pada kulit didaerah yang mudah dijangkau untuk menggaruk. Pemberian terapi antihistamin oral terbanyak adalah Klorfeniramini Maleat (CTM) $4 \mathrm{mg}$ yaitu 51 pasien $(72,9 \%)$, pemakaian terapi steroid oral terbanyak adalah Deksametason $0,5 \mathrm{mg}$ yaitu sebanyak 20 pasien $(28,6 \%)$, pemberian terapi topikal terbanyak untuk kasus LSK adalah Betametason 0,1\% krim sebanyak 36 orang. 


\section{Daftar Pustaka}

[1] Djuanda A. Ilmu penyakit kulit dan kelamin Edisi ketujuh. Jakarta: Badan Penerbit FK UI; 2017

[2] Novrizal R. Keefektifan hipnoterapi terhadap penurunan derajat kecemasan dan gatal pasien liken simpleks kronikus di poliklinik penyakit kulit dan kelamin RSDM Surakarta. Surakarta: 2010. Tersedia dalam: Perpustakaan.uns.ac.id.

[3] Goldsmith LA, Katz SI, Gilchrest BA, Paller AS, Leffell DJ, Wolff K. Fitzpatrick's Dermatology in general medicine Eight Edition. McGraw-Hill; 2011: 184-187

[4] Saraswati A, Tjibtaningrum A, Karyus A. Penatalaksanaan holistik penyakit kulit neurodermatitis sirkumskripta pada seorang pria lanjut usia di desa sukaraja V Gedong Tataan. JPM Ruwa Jurai. 2016.2(1):46-52.

[5] Ramineni HB, Manogna ASKL, Chandini M, Vidyadhara S. A case of neurodermatitis circumscripta with generalized pruritis. International journal of medical and health sciences. 2015. 4(1):145-146.

[6] Cohen AD, Andrews ID, Medvedovsky E, Peleg R, Vardi DA. Similarities between neuropathic pruritus sites and lichen simpleks chronicus sites. Israel Medical Association Journal. 2004.

[7] Ariyanti P, Suyoso S. Studi retrospektif: Pemahaman klinis liken simpleks chronicus (clinical understanding of lichen simpleks chonicus: A retrospective study). BIKKK. 2014; 26(2):122-126.

[8] Dicky R, Listiandoko W. Management of neurodermatitis on the elderly in Kota Karang Village. J Agromed Unila. 2014; 1(2):139-144.

[9] Ade, P. Identifikasi faktor resiko liken simpleks kronikus pada pasien di RSUP Dr. M. Djamil Padang. FK UNAND; 2016.

[10] Lynch PJ. Lichen simplex chronicus (atopic/ neurodermatitis) of the anogenital region. Dermatologic Therapy. 2004; 17(1):8-19.

[11] Georgieva F. Current Epidemiology of Lichen Simplex Chronicus. J of IMAB. 2016; 22(2):1221-1225.

[12] Saraswati A, Tjibtaningrum A, Karyus A. Penatalaksanaan holistik penyakit kulit neurodermatitis sirkumskripta pada seorang pria lanjut usia di desa sukaraja V Gedong Tataan. JPM Ruwa Jurai. 2016.2(1):46-52.

[13] Cohen AD, Andrews ID, Medvedovsky E, Peleg R, Vardi DA. Similarities between neuropathic pruritus sites and lichen simpleks chronicus sites. Israel Medical Association Journal. 2004.

[14] Ariyanti P, Suyoso S. Studi retrospektif: Pemahaman klinis liken simpleks chronicus (clinical understanding of lichen simpleks chonicus: A retrospective study). BIKKK. 2014; 26(2):122-126.
[15]Lipoff J. Dermatology simplified outlines and mnemonics. Springer London. 2016; 352.

[16] Torales J, Barrios I, Leczano L, Martino B. Lichen simpleks chronicus: Easy psychological interventions that every dermatologist should know. SM Dermatology Journal. 2016; 2(1):1-3.

[17] An J. Liu Y, Xiao S, Wang J, Geng S, Dong Y. Quality of life of patients with neurodermatitis. International Journal Science. 2013; 10(5):593598.

[18] Thappa D, Jaisankar T, Nath A, Rajalakshmi R. Lichen simplex chronicus of anogenital region: A clinic-etiological study. Indan J. Dermatology, Venerology and Leprology. 2011; 77(1):28.

[19] Nayak S, Shenoi S. Synopsis of training programme for dermatologist in non pharmacological (psychological) interventions in dermatology. Indian Journal Dermatology Venerology and Leprology. 2013; 79(2):275-278.

[20] Ermertcan A, Gencoglan G, Temeltas G, Horasan G, Deveci A, Ozturk F. Sexual dysfunction in female patients with neurodermatitis. Journal of Andrology. 2011; 32(2):165-169.

[21]Juan CK, Chen HJ, Shen JL, Kao CH. Lichen simpleks chonicus associated with erectile dysfunction: A population-based retrospective cohort study. PLoS One. 2015; 10(6).

[22] Lotti T, Buggiani G, Prignano F. Prurigo nodularis and lichen simpleks chronicus. Dermatologic Therapy. 2008; 21(1)42-46.

[23] Voicu C, Tebeica T, Zanardelli M, Mangarov H, Lotti $\mathrm{T}$, Wollina $\mathrm{U}$, et.al. Lichen simplex chronicus as an essensial part of the dermatologist masquerade. Macedonian Journal Medical Science. 2017; 5(4):556-557.

[24] Bobonich MA, Nolen MA. Dermatology for advanced practice clinicians. Edition One. Wolters Kluwer; p.36.

[25] Habif TP. Clinical dermatology: A color guide to diagnosis and therapy, Edition 6: Elsevier;2016. p. 114-117.

[26] Yosipovitch G,Segeng M, Chan Y, Goon A, Ngim S, Goh C. The effect of topically applied aspirin on localized circumscribed neurodermatitis. Journal of the American Academy of Dermatology. 2001; 45(6):910-913.

[27] Tiengo C, Deluca J, Belloni-Fortina A, Salmaso R, Galifi F, Alaibac M. Occurrence of squamous cell carcinoma in an area of lichen simplex chronicus: Case report and pathogenetic hypothesis. Journal of Cutaneus Medicine and Surgery. 2012; 16(5):350-352. 
[28] Charifa A, Badri T. Lichen, Simplex Chronicus. StatPearls Publishing, Treasure Island (FL). 2018

[29] Ubaidi BA. Evaluate patient with lichen simplex chronicus. Bahrain Medical Bulletin. 2016; 38(3): 160-161. 